\title{
Mexican Psittacids held in captivity in Puerto Escondido, Oaxaca and their welfare conditions
}

\section{Psitacidos mexicanos mantenidos en cautiverio en Puerto Escondido, Oaxaca y sus condiciones de salud}

\section{Alejandra Buenrostro- \\ Silva ${ }^{1} \mathbb{D}$, \\ Eloisa Gutiérrez-Sampé ${ }^{1}$, \\ Jesús García-Grajales ${ }^{1 *}$ [ \\ ${ }^{1}$ Universidad del Mar campus \\ Puerto Escondido. Km. 2.5, \\ Carr. Federal Puerto - Sola \\ de Vega, CP. 71980. Puerto \\ Escondido, Oaxaca, México.}

*Corresponding author:

archosaurio@yahoo.com.mx

Scientific note

Received: january 18, 2021

Accepted: may 14, 2021

How to cite: Buenrostro-Silva

A, Gutiérrez-Sampé E, García-

Grajales J (2021) Mexican

Psittacids held in captivity in

Puerto Escondido, Oaxaca

and their welfare conditions.

Ecosistemas y Recursos

Agropecuarios 8(2): e2809.

DOI: 10.19136/era.a8n2.2809
ABSTRACT. Many bird species such as parrots and parakeets are held in captivity in various cities in Mexico as ornaments and pets. This study aimed to record the number of Psittacid species kept in captivity in the city of Puerto Escondido, Oaxaca, along with assessing their welfare conditions. Information was obtained from 195 bird keepers from March to May 2014, using the "snowball" interview technique. Information about their birds' cost of acquisition, the season of sale, feeding and care were recorded. Additionally, an assessment of the welfare status of each bird was performed. A total of 245 Psittacid individuals were recorded, and all were illegal. Eupsittula canicularis was the most common species, and Amazona autumnalis was the least common. The most frequent welfare condition found was the absence of feathers (73.5\%), probably associated with excess stress caused by overcrowding. Keeping wild birds in captivity continues clandestinely; therefore, is necessary to create a local strategy that helps prevent the domestic use of the Psittacids as pets.

Key words: Oaxaca, parakeets, parrots, threatened, welfare.

RESUMEN. Muchas especies de aves, entre ellas los psitácidos, son mantenidos en cautiverio en varias ciudades de México como mascotas o animales de compañía. El objetivo del estudio fue registrar a las especies de psitácidos que son mantenidos en cautiverio en la ciudad de Puerto Escondido, Oaxaca; y sus condiciones de bienestar. La información fue obtenida de 195 propietarios entrevistados entre marzo y mayo de 2014. A los que se les recabó información sobre los costos de adquisición, la temporada de venta, así como el tipo de alimentación y cuidados. Adicionalmente, realizamos una evaluación física del estado de bienestar de cada ave cautiva. Se registraron 245 psittacidos en cautiverio los fueron obtenidos de forma ilegal; Eupsittula canicularis fue la especie más común y Amazona autumnalis la menos frecuente. La condición de salud más frecuente registrada fue la presencia de individuos con ausencia de plumas (73.5\%), probablemente asociado al estrés causado por hacinamiento. Es necesario la creación de estrategias locales que ayuden a prevenir el uso de estos organismos como mascotas.

Palabras clave: Amenazadas, bienestar, loros, Oaxaca, pericos. 


\section{INTRODUCTION}

For centuries across the world, animals and plants have been taken from the wilderness to be traded for profit or personal use (Omandi et al. 2004, Roldán-Clarà et al. 2014). Among the animals and plants sold worldwide, birds are the most likely to be exploited (Iñigo-Elias and Ramos 1991, Roldán-Clarà et al. 2014). Neotropical psittacids are of primary conservation concern, with nearly $28 \%$ of species affected by poaching for the illegal pet trade (Olah et al. 2016).

In Mexico, species from the family Psittacidae represent a high percentage of the species at risk (Cantú et al. 2007), due to habitat loss in temperate and tropical forests (Monterrubio-Rico et al. 2016), as well as local and regional pet trade exploitation (Mas et al. 2004, Cantú et al. 2007, Pires and Moreto 2016). Animal trafficking and overexploitation have adversely affected all Psittacid species to the point of placing them under restriction status in Mexico, declaring them in danger of extinction, threatened or under special protection laws (SEMARNAT 2010, Pires and Moreto 2016). Nonetheless, bird keeping is an ancient and widespread tradition that still prevails in Mexico (Cantú et al. 2007, de Oliveira et al. 2018).

The Psittacidae family's habitat loss is mainly due to the looting of nests and the selective, clandestine logging of matured trees (Monterrubio-Rico et al. 2007). The Psittacidae species are often removed from their nesting areas for their beautiful feathers, and some species are captured for their ability to imitate human voices (Cantú et al. 2007). In Mexico, the Psittacids' attractiveness has generated domestication similar to that of the dog or the cat. During pre-Hispanic times, these species were considered a bridge of communication with the divine; therefore, they were kept by people and subsequently provided good company (Valadez-Azúa 2003).

During the Spanish colonization, the domestication of parrots and parakeets increased (Cantú et al. 2007). The current wild populations of Psittacidae have experienced peaks of remotion (Thomsen and Henley 1987); consequently, the Convention on International Trade in Endangered Species of Wild Flora and Fauna (CITES) has included all psittacid species in its appendices I and II (CITES 2020). The overexploitation and illegal trade of psittacids still exists in Mexico (Cantú et al. 2007), but few studies have evaluated this situation in Mexico (Iñigo and Ramos 1991, Cantú and Sánchez 1996, Gobbi et al. 1996). Human society continues to demand the illegal sale of these species, despite a total ban by the Mexican government (Cantú and Sánchez 2012).

Many psittacid species are held in illegal captivity as ornaments or pets in various Mexican cities, and if there are conditions of overcrowding, poor food practices or inadequate care by the owners, this can cause stress (Gómez-Álvarez et al. 2005). There has been no previous research, however, documenting the species' richness and their conditions in captivity. This study aimed to record the Psittacidae species held in captivity in Puerto Escondido, Oaxaca, as well as their welfare conditions.

\section{MATERIALS AND METHODS}

\section{Study area}

Puerto Escondido is a developing tourist city located on the central coast of Oaxaca. Currently, the estimated population of this city is about 25,910 inhabitants. Spanish is the primary language, but English is commonly used as a tourist language. Other native languages are also spoken, such as Chatino, Zapoteco and Mixteco (Secretaría de Desarrollo Social 2012, Martínez-Sánchez et al. 2019). The climate is warm and sub-humid, with an annual mean temperature of $26.8^{\circ} \mathrm{C}$ and annual mean precipitation of 2245 mm (García 1973).

\section{Data collection}

Information was obtained from 195 bird keepers in Puerto Escondido during opportunistic visits from March to May 2014. The city was divided into four sections: north, south, east and west, based on the cardinal points of the city. Each section included a different number of colonies (Figure 1). Based on the first interviews, further respondents were selected using the "snowball"technique (Bailey 


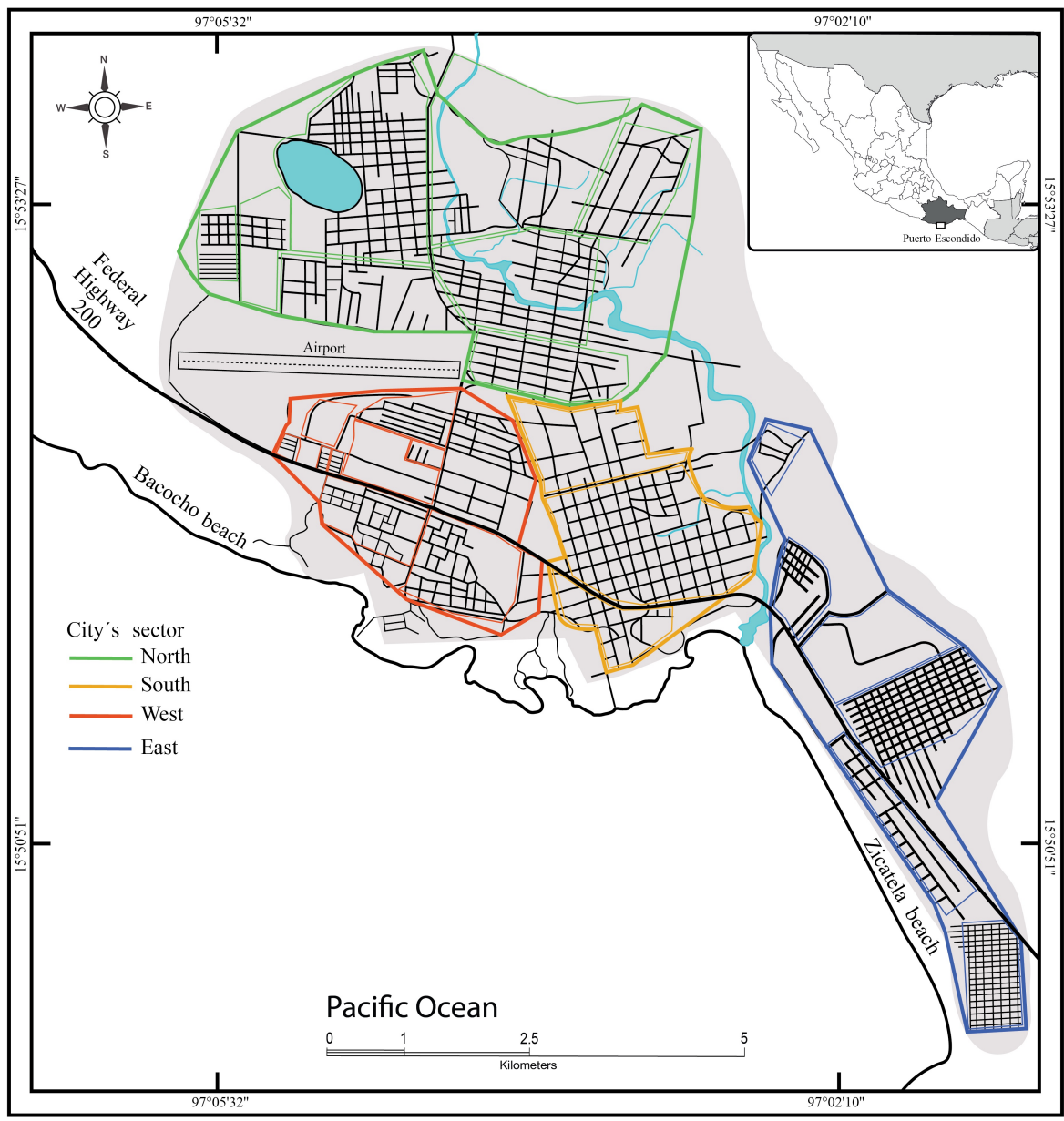

Figure 1. Sectors and colonies surveyed in Puerto Escondido, Oaxaca, Mexico.

1982), by which the initial respondent indicated other respondents the researcher should consult.

Initially, we built trust with the respondents through direct informal conversations directly at the Psittacid owners' homes, in which the nature and objectives of the research were explained, and consent to record the information was requested (Albuquerque et al. 2014). Later, we applied semi-structured interviews supplemented by informal conversations (Albuquerque et al. 2010, Huntington 2000). The forms used in the interviews were designed to collect information about the use of psittacids as pets, the cost of acquisition, seasons of sales, and also feeding and care. Additionally, we conducted an assessment of each bird's welfare status based on its feathers and body characteristics, without handling the ani- mals to avoid causing them stress. The welfare conditions were evaluated as the following: 1) good conditions for the birds with normal behavior and regular feathering colorations and conditions; 2) absence of feathers; 3) presence of dirty cloacal feathers, indicative of a digestive disorder; 4) beak deformations and 5) missing nails or phalanges on the legs. In this study we did not assess the age or sex of the birds because both present difficulties due to the absence of sexual dimorphism and because traditional sexing methods are traumatic or require extensive protocols that do not work on these species (Betancourt et al. 2017).

All species in captivity were identified at the lowest possible taxonomic level, based on the specialized literature by Howell and Web (1995) and Van Perlo (2006). The scientific nomenclature and 
common names follow Chesser et al. (2020). The current status of each species was based on Mexican Official Norm 059 (SEMARNAT 2010), the Convention on International Trade in Endangered Species of Wild Flora and Fauna list (CITES 2020) and the International Union for Conservation of Nature (IUCN 2020).

A data matrix was created for each section of the city and recorded in an Excel 2019 file. For the analysis, we employed the central tendency measures and distribution frequency. To determine the relationship between the age and education level of the interviewees and the number of species the held captive, Spearman non-parametric correlations were performed using XLStat statistical software (Addinsoft, Inc.).

Additionally, a parametric one-way ANOVA test was used to examine differences among the number of psittacids in the various sectors of the city. Previously, we had tested the normality and homogeneity of variance of the data. To detect significative differences, we performed a posteriori Tukey test. Similarly, a parametric one-way ANOVA test was used to examine differences among welfare conditions of psittacids and the different sectors.

\section{RESULTS AND DISCUSSION}

A total of 245 individuals of Psittacidae belonging to six species were recorded as captive pets in the city of Puerto Escondido. Eupsittula canicularis was the most frequent species $(75.9 \%)$, while Amazona autumnalis was the least frequent $(1.03 \%$, Table 1). All the species recorded were acquired via illegal trade. Other species such as $A$. autumnalis and Amazona farinosa guatemalae deserve special mention as a captive species since the Oaxacan coastal region is not within their normal distribution range. According to Monterrubio-Rico et al. (2016), of the six psittacids species recorded in our study, $A$. autumnalis and $A$. farinosa guatemalae were the species considered outside their current and historical distribution. Most likely, these species came here through regional traffic routes, such as the Gulf route that has a connection to the Isthmus of Tehuantepec in Oaxaca (Cantú et al. 2007).

The illegal trade of psittacids in Puerto Escondido was not surprising since bird keepers tipically choose these birds for their colors, ease of maintenance and in some cases, ability to imitate human speech (Cantú et al. 2007). In other countries, the order Passeriformes is the preferred group among bird keepers (De Oliveira et al. 2018); but on the coast of Oaxaca, bird keepers prefer the Psittacidae species.

No significant correlations were found between the species richness of Psittacidae and the respondents' age or education level $(p=0.852$ and $p=$ 0.632 , respectively). Although legislation prohibits the use of the Psittacidae species as pets, it has been found that the illegal trade among these species has been increasing in recent years (Cantú et al. 2007). Between 2017 and 2019, the Federal Environmental Protection Agency (PROFEPA is its acronym in Spanish) confiscated 2427 parakeets and parrots, of which the main species captured were E. canicularis, $A$. autumnalis and $A$. oratrix, among others (PROFEPA 2019). De Oliveira et al. (2018) pointed out that it is necessary to consider the sociocultural context, such as understanding the relationship between the owners and their birds, when implementing conservation actions. In this study, however, we found no evidence of correlations between species richness and the respondents' age or educational level, indicating those characteristics have no connection with the animals' acquisition.

The city's eastern sector presented the most significant number of birds in captivity $(\mathrm{n}=104$, $42.4 \%$ ), while the western sector presented the smallest number $(n=24,9.8 \%$, Table 1a). The differences among the number of psittacids in different sectors was significant $(F=7.741$; $d f=3$; $P$ $=0.0002$, Table 2). In the eastern sector, the Lázaro Cárdenas colony presented 17 individuals, followed by the Libertad colony (12 individuals) and the Independencia colony (11 individuals). In the northern sector, the Aeropuerto colony presented the highest number of individuals in captivity with 24 . 
Table 1. Psittacid species recorded in captivity in Puerto Escondido, Oaxaca, Mexico.

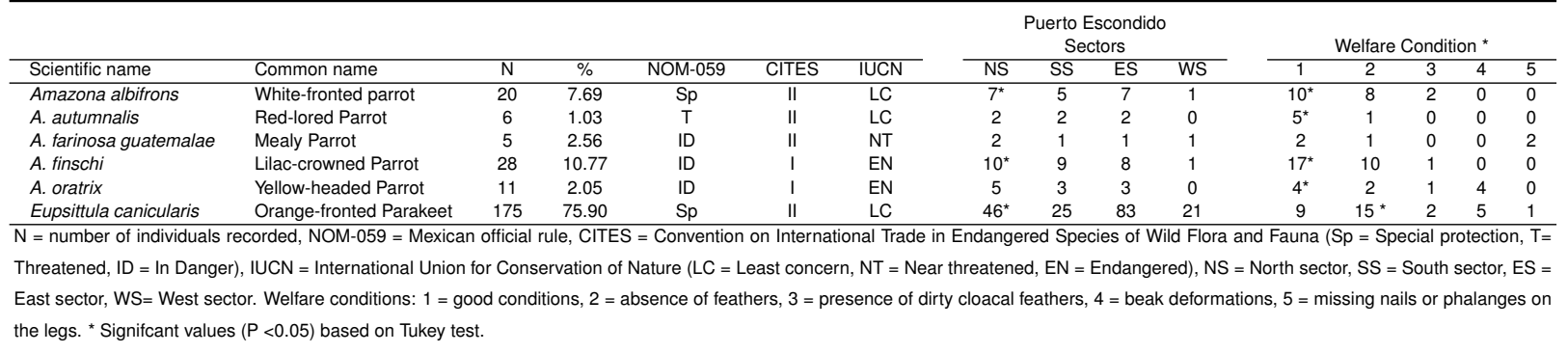

Table 2. Statistic differences among the number of psittacids and welfare conditions in different sectors of Puerto Escondido, Oaxaca.

\begin{tabular}{lllll}
\hline & \multicolumn{5}{c}{ Number of psittacids } \\
\hline Source & $\mathrm{df}$ & $\mathrm{MS}$ & $\mathrm{F}$ & $\mathrm{P}$ \\
Between sectors & 3 & 0.009056 & 7.741 & 0.0002 \\
Inside sectors & 3 & 0.005418 & & \\
\cline { 2 - 5 } & \multicolumn{5}{c}{ welfare conditions in different sectors } \\
\cline { 2 - 5 } Between welfare conditions & 3 & 0.006813 & 7.561 & 0.0007 \\
Inside welfare conditions & 3 & 0.009679 & & \\
\hline
\end{tabular}

The eastern and northern sectors probably had higher numbers of captive birds because those are the areas with the highest degree of marginalization, and therefore lower cultural and environmental awareness. On the other hand, the southern and western sectors tend to have better living conditions and are the city's tourist areas, and consequently are the sections with greater environmental awareness. Olah et al. (2016) explained that urbanization can produce far-reaching transformation but is also linked to broadscale environmental degradation.

Of the 195 psittacid owners, only 133 agreed to be interviewed, and the rest stated they were afraid to learn that it is illegal to keep these species in captivity. The majority of interviewees were born in Puerto Escondido (41.3\%), and the rest came from areas close to the region. Of the people interviewed, $61 \%(n=81)$ were housewives, $11 \%(n=14)$ were merchants and the rest had different occupations. The interviewees' age fluctuated between 15 and 65 years; with $8 \%$ (n $=109)$ were females and $18 \%(n=24)$ males.

Most of the psittacid owners (64.6\%) had only one bird; $29.7 \%$ had two; $22.1 \%$ had three; $6.2 \%$ had four and $3.1 \%$ had six individuals of the same species. Of these, only $11.8 \%$ of the owners had exotic psittacids. All the owners were unaware of the type of species they had. Among them, 58\% ( $n=$ 68 ) of the owners with two or more psittacids kept the animals together in a single cage.

Most captive birds spend their entire lives confined in accommodations that humans have designed; but often, the birds' necessities are not met (Hawkins 2010). Housing for birds should promote their physical and psychological welfare, facilitate and encourage appropriate behaviors and minimize the occurrence of undesirable behaviors. When these needs are not met or are inadequate, it can result in poor physical conditions and diseases can result (Hawkins 2010). In our study, we recorded animals with symptoms of serious welfare problems, probably caused by inappropriate husbandry.

A high percentage $(45 \%)$ of psittacids held in captivity were gifts, others were bought (38\%) and the rest of the owners chose not to declare the form of obtention. Of all these animals, $47 \%$ of the individuals arrived during the chick stage, others came when they started to feather $(30 \%)$ and the rest came when they were two months or older.

The use of Psittacid species as pets is directly associated with their trade. Most of the respondents $(n=133)$ stated that even though they knew about the illegality of keeping these species in captivity, they still obtained the birds as pets or received them as gifts. The Psittacidae family is strongly affected by global trade (Roldán Clarà et al. 2014) and is the second most traded bird family in the world. Our results show these species as the favorites for being kept in captivity. This is consistent with the information indicated by Thomsen et al. (1991), that the Psittacidae family occupies the second position in the bird trade, only after the passerines because that group is very 
charismatic and is therefore highly valued in the market (Iñigo-Elias and Ramos 1991).

Regarding the areas of sale and purchase, a high percentage $(62 \%)$ of the interviewees declared their birds were obtained from the municipal market; $22 \%$ declared their birds were bought on the street; and the rest $(16 \%)$ said their birds were obtained through orders. The cost fluctuated around $\$ 150$ Mexican pesos for parakeet chicks, and between $\$ 300$ and $\$ 500$ Mexican pesos for parrot chicks.

Supply and demand usually define the prices of illegal parrots and parakeets, and the sex of the individual does not influence the price (Cantú et al. 2007). The prices reported here in Puerto Escondido are lower than those presented by Durán and Godínez (2020), who reported purchasing prices of psittacids between $\$ 500$ and $\$ 1500$ Mexican pesos in the Sierra de Abra Tanchipa Biosphere Reserve in San Luis Potosí state, but are higher than those presented by Cantú et al. (2007). Exotic species like $M$. undulatus are rare and are not included in the list of exotic birds reported by Cantú et al. (2007).

All owners mentioned being uncertain about the sex of their animals, but they had heard rumors about identifying sex through plumage and body characteristics, such as the shape and thickness of the head. Concerning food, a high percentage of the owners (83\%) provided sunflower seeds, birdseed, cornmeal dough and the fruit of Terminalia catappa. A low percentage of owners (5\%) provided additional nourishment, such as proteins, and the rest of them did not provide any extra care.

\section{Welfare conditions}

In general, the most common welfare condition found was the absence of feathers (73.5\%), and the least frequent health problem was missing nails and phalanges on the legs (1.2\%) (Table 1). The eastern sector of the city presented the most significant percentage of individuals with absence of feathers (47\%), followed by the northern sector (19.1\%), the southern sector $(15.91 \%)$ and the western sector $(10.1 \%)$. The differences among welfare conditions of psittacids in various sectors were significant $(F=7.561 ; d f=3 ; P=$ 0.0007). Additionally, all birds showed that their flight feathers had been cut by the owners.

Feeding is a crucial factor in the well-being and development of birds, and it determines the success of captivity management (Allgayer and Cziulik 2007). In our study, although the owners offered a diet based on birdseed, cornmeal dough and fruits like mango, banana, and Terminalia catappa, a high percentage of birds presented an absence of feathers. There are two possible explanations for this: 1) excess stress probably caused by overcrowding, which causes the birds to mutilate their feathers or 2) the presence of psittacosis, a disease associated with these species, which is caused by the Chlamydia psittaci bacteria, a micro-organism that mainly targets individuals that are immune-depressed (Gómez-Álvarez et al. 2005). Our study also found that owners do not provide the proper vitamins and calcium-based medicines to maintain good health. This situation is different from the one reported by de Oliveira et al. (2018) in Lagoa Seca, Brazil.

Although none of the previous studies are mentioned, the practice of the cutting off flight feathers is common among bird keepers in Puerto Escondido to make sure the birds always stay close, preventing them from escaping. This practice does not affect the development or conduct of the birds; however, it exposes them to predation by domestic cats in the absence of constant care.

More government participation is needed to create a strategy that helps prevent the use of Psittacids as pets by providing information and lecturing at local events and in schools. To create conscientiousness about the mistreatment and mortality rates of the species, government, no government associations, academic institutions and members of the society need also to post public notices in a variety of media sources; for example, on local television, radio and websites and in local newspaper.

All species of the Psittacidae family recorded in this study that are marketed and kept as pets are on the Mexican list of threatened species and were acquired via illegal trade. Eupsittula canicularis was the most frequent species kept in captivity. Puerto Escondido's eastern sector presented the most significant number of birds in captivity. A 
high percentage of psittacids held in captivity were

gifts and others were bought. In general, the most common physical problem found was the absence of feathers, and the least frequent health issue was missing nails and phalanges on the legs. Although keeping wild birds in captivity is prohibited by Mexican environmental agencies, this practice continues clandestinely in a widespread manner, and our results demonstrate this situation.

\section{ACKNOWLEDGEMENTS}

We give thanks to the Universidad del Mar (UMAR) for its logistic support. We thank the group of students who contributed to conducting the surveys. Thanks to Allison Tai Rosewicz (UMAR) for her help with the language review. JGG thanks the Sistema Nacional de Investigadores (SNI) for its grant.

\section{LITERATURE CITED}

Albuquerque UP, Lucena RP, Cunha LC (2010) Métodos e técnicas na pesquisa etnobiológica y etnoecológica. NUPPEA, Recife, Portugal. 280p.

Albuquerque UP, Cunha L, Lucena R, Alves RRN (2014) Methods and techniques in ethnobiology and ethnoecology. 1 Ed., Springer. New York, USA. 113p.

Allgayer MC, Cziulik M (2007) Reprodução de psitacídeos em cativeiro. Revista Brasileira de Reprodução Animal 31: 344-350.

Bailey K (1982) Methods of social reached. 2nd Ed. The Free Press. New York, USA. 271p.

Cantú JC, Sánchez ME (1996) Tráfico ilegal de pericos mexicanos. Naturaleza y Tráfico 1: 14-18.

Cantú JC, Sánchez Saldaña ME, Grosselet M, Silva Gámez J (2007) Tráfico ilegal de pericos en México. Una evaluación detallada. Defender of Widlife. Washington, DC, USA. 75p.

Cantú JC, Sánchez ME (2012) Estudio de caso: El tráfico ilegal de pericos silvestres en México. Defender of Wildlife, Teyeliz, A.C., México. 25p.

Chesser RT, Billerman SM, Burns KJ, Cicero C, Dunn JL, Kratter AW, Lovette IJ, Mason NA, Rasmussen PC, Remsen JV, Stotz DF, Winker K (2020) Check-list of North American Birds (online). American Ornithological Society. http://checklist.aou.org/tax. Data consuted: November 5, 2020.

CITES (2020) Cheklist of CITES species. Official list of CITES-listed species (scientific names) and their associated scientific synonyms and common names. https://checklist.cites.org/. Data consulted: August 5, 2020.

SEMARNAT (2010) Norma Oficial Mexicana NOM-059-SEMARNAT-2010, que determina las especies de flora y fauna silvestre terrestres y acuáticas; endémicas, amenazadas, en peligro de extinción y sujetas a protección especial. Órgano del Gobierno Constitucional de los Estados, Gobierno Federal, México. Diario Oficial de la Federación.

de Oliveira WSL, Faria Lopes S, Nóbrega Alvez R (2018) Understanding the motivations for keeping wild birds in the semi-arid region of Brazil. Journal of Ethnobiology and Etmomedicine 14: Article 41 DOI: 10.1186/s130 02-018-0243-6.

Durán A, Godínez O (2020) Los loros en cautiverio: extinción por admiración. Universitarios Potosinos 248: 4-8.

García E (2004) Modificaciones al sistema de clasificación climática de Köppen para adaptarlo a las condiciones de la República Mexicana. Quinta edición, Instituto de Geografía. Universidad Nacional Autónoma de México. 96p. 
Gobbi J, Sheeline L, Rose D, De Ferrari G (1996) Parrot smuggling across the Texas-Mexico border. Traffic-USA. World Wildlife Fund. New York, USA. 265p.

Gómez-Álvarez G, Valadez Azúa R, Solano CT, Reyes Gómez SR (2005) Manejo en cautiverio de psitácidos utilizados como aves de ornato y compañía. AMMVEPE 16: 5-17.

Hawkins P (2010) The welfare implications of housing captive wild and domesticated birds. In: Duncan IJH, Hawkins $\mathrm{P}$ (eds.) The welfare of domesticated fowl and other captive birds. Springer Science-Business Media. New York, USA. pp: 53-102.

Howell S, Webb, S (1995) A guide to the birds of Mexico and Northern Central America. Oxford University Press. USA. 623p.

Huntington HP (2000) Using traditional ecological knowledge in science: methods and applications. Ecology Applied 10: 1270-1274.

Iñigo-Elias EE, Ramos MA (1991) The Psittacinae trade in Mexico. In: Robinson JG, Redford K H (eds) Neotropical wildlife use and conservation. University of Chicago Press. Chicago, USA. pp: 380-392.

Olah G, Butchart SHM, Symes A, Guzmán IM, Cunningham R, Brightsmith DJ, Heinsohn R (2016) Ecological and socio-economic factors affecting extinction risk in parrots. Biodiversity and Conservation 25: 205-223.

Omandi P, Bitole E, Kagin J (2004) Managing human-elephant conflicts: the Kenyan experience. Pachyderm 36 : 80-86.

Martínez-Sánchez A, Rodríguez-Díaz A, Aguirre M (2019) Hábitos y prácticas etnoentomológicas en la comunidad de Puerto Escondido, Oaxaca. Avances en Ciencia, Salud y Medicina 6: 9-15.

Mas JF, Velázquez A, Díaz-Gallegos JR, Mayorga-Saucedo R, Alcántara C, Bocco, G (2004) Assessing land use/cover changes: a nation-wide multidate spatial database for Mexico. International Journal of Applied Earth Observation and Geoinformation 5: 249-261.

Monterrubio-Rico TC, Villaseñor-Gómez LE, Marín-Togo MC, López-Córdova EA, Fabian-Turja B, Sorani-Dalbon V (2007) Distribución histórica y actual del loro cabeza amarilla (Amazona oratrix) en la costa central del Pacífico mexicano: ventajas y limitaciones en el uso de GARP en especies bajo presión de tráfico. Ornitología Neotropical 18: 263-276.

Monterrubio-Rico T, Charre-Medellín JF, Pacheco-Figueroa C, Arriaga-Weiss S, Valdez-Leal J. D, Cancino-Murillo Y, Segura-Escalona G, Bonilla-Ruz C, Rubio-Rocha Y (2016) Distribución potencial histórica y contemporánea de la familia Psittacidae en México. Revista Mexicana de Biodiversidad 87: 1103-117.

Pires SF, Moreto WD (2016) The illegal wildlife trade. Oxford Handbook Online, University of Florida, USA. 237p.

PROFEPA (2019) Tráfico ilegal de loros en México. Gobierno de México, Ciudad de México. https://www.gob.mx/ profepa/es/articulos/trafico-ilegal-de-loros-en-mexico?idiom=es . Data consulted: March 17, 2020.

Roldán-Clarà B, López-Medellín X, Espejel I, Arellano E (2014) Literature review of the use of birds as pets in Latin-America, with a detailed perspective on Mexico. Ethnobiology and Conservation 3: 1-18.

Secretaría de Desarrollo Social (2012) Atlas de riesgos naturales en el municipio de San Pedro Mixtepec, Oaxaca. Gobierno del Estado de Oaxaca. http://www.anr.gob.mx/Docs/2012/20318. Data consulted: June 23, 2020.

Thomsen JB, Brautigam R (1991) Sustainable use of Parrots. In: Beissinger, SR, Snyder NFR (eds) New world Parrots in Crisis. Solutions from conservation Biology Smithsonian. USA. pp: 359-379.

Thomsen JB, Henley G (1987) Bird trade bird bans. TRAFFIC 7: 15-26. 
Valadez-Azúa R (2003) Domesticación y zootecnia en el México antiguo. Imagen Veterinaria 3: 21-29.

Van Perlo B (2006) Birds of Mexico and Central America. Princeton University Press. New Jersey, USA. 526p. 